A. J. 62, No. 1252:

ERRATUM

Page 248, Titles of Additional Papers, correct to read Segre, Sergio and Vardya, Mahendra, S. A stellar interior model for Algol A.

\title{
NEW BOOKS RECEIVED
}

The Planet Venus, by Patrick Moore. Published by the Macmillan Company, New York. Price $\$ 3.00$.

\section{NOTICES}

The Directors of the Benjamin Apthorp Gould Fund of the National Academy of Sciences invite applications for appropriations to support publication of the results of meritorious astronomical researches, which are not suitable for publication in journals, either by reason of their length or otherwise. Preference will be given to branches of astronomy closest to the interest of Benjamin Apthorp Gould, to investigators in his own country or of his own nationality, and to applications received before June 30 , 1958.

Applications should be in triplicate, and may be sent to Mr. Clemence.

G. M. Clemence

LyMAN SPITZER, JR. Joel Stebbins

I958 January

This number completes Volume 62 of The Astronomical Journal. The publication of this volume was made possible by subsidies received from the Benjamin Apthorp Gould and the James Craig Watson Funds, administered by the National Academy of Sciences; and from the E. W. Brown Fund, administered by the American Astronomical Society. 